\title{
Effect of Gynura procumbens Extracts on Anti-Proliferative Activity and its Associated Morphological Changes of Human Glioblastoma multiforme Cell Line (U-87)
}

\author{
Mohd Adzim Khalili Rohin 1,3,4, Mimie Noratiqah Jumli' ${ }^{1}$ Norhaslinda Ridzwan' ${ }^{1}$ Atif Amin Baig', \\ Ahmad Zubaidi Abdul Latif ${ }^{2}$, Norhayati Abd Hadi*
}

\section{Mohd Adzim Khalili Ro- hin $^{1,3,4}$, Mimie Noratiqah Jumli ${ }^{1}$, Norhaslinda Ridzwan', Atif Amin Baig², Ahmad Zubaidi Abdul Latif', Norhayati Abd Hadi $^{1 *}$}

'School of Nutrition and Dietetic, Faculty of Health Sciences, Universiti Sultan Zainal Abidin (UniSZA), Gong Badak Campus, 21300 Kuala Nerus, Terengganu, MALAYSIA. ${ }^{2}$ Faculty of Medicine, Universiti Sultan Zainal Abidin (UniSZA), Medical Campus, 20400 Kuala Terengganu, Terengganu, MALAYSIA. ${ }^{3}$ Centre for Continuing Education (CCE), Universiti Sultan Zainal Abidin (UniSZA), Gong Badak Campus, 21300 Kuala Nerus, Terengganu, MALAYSIA.

${ }^{4}$ Institute for Community (Health) Development, Universiti Sultan Zainal Abidin (UniSZA), Gong Badak Campus, 21300 Kuala Nerus, Terengganu, MALAYSIA.

\section{Correspondence}

Norhayati Abd Hadi

School of Nutrition and Dietetic, Faculty of Health Sciences, Universiti Sultan Zainal Abidin (UniSZA), Gong Badak Campus, 21300 Kuala Nerus, Terengganu, MALAYSIA

Phone no: +609 6688514

E-mail: norhayatihadi@unisza.edu.my

History

- Submission Date: 14-11-2017;

- Review completed: 22-12-2017.

- Accepted Date: 08-01-2018

DOI : 10.5530/pj.2018.3.81

Article Available online

http://www.phcogj.com/v10/i3

Copyright

(C) 2018 Phcog.Net. This is an openaccess article distributed under the terms of the Creative Commons Attribution 4.0 International license.

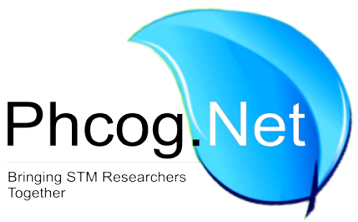

\begin{abstract}
Objective: Gynura procumbens (Lour.) Merr is a well-known traditional herb and is widely used for traditional medicine by human. Previous clinical studies have shown the benefit effect of this leaves with inflammation, high blood pressure and others. This study aims to investigate the effect of methanol, ethanol, and ethyl acetate extracts of Gynura procumbens on U-87 cell line, human Glioblastoma multiforme cell line. Methods: In the present study, effect of methanol, ethanol and ethyl acetate extracts on U-87 cell line was determined by MTT-based anti-proliferative assay and any significant changes to the cells towards apoptotic changes was observed under a light microscope. Results: The ethanol and methanol extracts of Gynura procumbens was found to have high anti-proliferative effect on U-87 cell line with $\mathrm{IC}_{50}$ less than $20 \mu \mathrm{g} / \mathrm{ml}$. By comparing $\mathrm{IC}_{50}$ value, ethanol and methanol extracts of Gynura procumbens had high potential for anti-proliferative effect on U- 87 cell line. Therefore, ethanol and methanol extracts can be a potential anti-proliferative effect on U-87 cell line. Conclusion: To the best of our knowledge, this is the first study of exploring the effect of Gynura procumbens extracts using three different polarity (methanol, ethanol, ethyl acetate) effect on U-87 cell line, Human Glioblastoma multiforme cells.
\end{abstract}

Key words: Gynura procumbens, Ethanol, Methanol, U87 cell line, Antiproliferative.

\section{INTRODUCTION}

Glioma is a malignant tumor of the glial tissue has reported being rapidly proliferation with diffuse invasion rate among common brain tumors in adult. Glioblastoma Multiforme (GBM) is a brain tumour which is also called IV astrocytoma. ${ }^{1}$ Patient with GBM has a very poor prognosis, with a median survival rate of 14 months' post-surgical resection, chemotherapy, and radiation. ${ }^{2}$ Oxidative processes in the human body produce free radicals as by products, primarily reactive oxygen species (ROS) and it is associated with cancer occurrence. ${ }^{3}$ Elevated levels of ROS and down regulation of ROS scavengers and antioxidant enzymes are associated with various human diseases, including cancers. ${ }^{4}$ Hence, new effective alternative treatments are required to improve outcomes for patients with malignant gliomas.

Enormous bioactive compounds contained in plant can contribute to be an antioxidant that protect human body from free radical scavenging activity. It has been a secondary metabolite produced to defend against oxidative damage by free radical which can cause cancer. Currently, antioxidants had been applied in food and beverages industry, cosmetic industry and nutrition and supplement industry to fight against oxidative damages. ${ }^{5}$ Gynura procumbens is a plant that contains abundant bioactive compound which can provide benefit to human health. It commonly found in tropical Asian countries such as China, Thailand, Indonesia, Vietnam and Malaysia. In Malay language, G. procumbens is called Sambung Nyawa which means "prolongation of life" whereas, in Chinese language, it is called Bai Bing Cao meaning of "100 ailments". ${ }^{6}$

The leaves of this plant often consumed in diet and studies showed that leaves contents do not have any toxic effect. ${ }^{7}$ It contains a lot of bioactive compounds such as flavonoid, phenolic acid and glycosides. ${ }^{8}$ Gynura procumbens is one of the herbal plants used for traditional treatment of various health diseases and disorder such as rash, kidney disorder, hypertension, diabetes mellitus and cancer. ${ }^{9}$ Previous clinical studies have reported the beneficial effects of herbal medicines on the survival, immune modulation, and quality of life (QOL) of cancer patients, which their use in combination with conventional therapeutics.

The previous study already stated Gynura procumbens has been used as post-treatment studies along with chemotherapy (doxorubicin) and showed a strong synergistic effect against colon cancer cells. ${ }^{8}$ Also,

Cite this article: Rohin MAK, Jumli MN, Ridzwan N, Baig AA, Latif AZA, Hadi NA. Effects of Gynura procumbens Extracts on Anti-Proliferative Activity and its Associated Morphological Changes of Human Glioblastoma Multiforme Cell Line (U-87). Pharmacog J. 2018;10(3):492-6. 
Gynura procumbens appears to be an effective chemotherapeutic agent against a wide range of cancer cell types, and it exerts its anticancer activities via the modulation of various points of carcinogenesis. Therefore, this study focused on study the effects of Gynura procumbens extracts to anti-proliferative activity towards associated morphological changes of human Glioblastoma multiforme cell lines (U-87).

\section{MATERIALS AND METHODS}

\section{Extraction and Isolation of Gynura procumbens}

Gynura procumbens leaf extracted according to the method described by the previous studied. ${ }^{9}$ The Gynura procumbens obtained from Kuala Terengganu, Terengganu, Malaysia. The leaves were washed with running tap water and dried for $24-48$ h by using first cooled vacuum oven (Memmert, Germany) at $40^{\circ} \mathrm{C}$. Dried Gynura procumbens leaves macerated into powdered form. After that, each of $30 \mathrm{~g}$ of Gynura procumbens powdered was soaked into three different polar solvents (methanol, ethanol and ethyl acetate) with a ratio 1:10 for 24-h. Finally, all the extracts from all solvent were filtered using Whatman ${ }^{\circledR}$ No. 41 filter paper (pore size 20-25 $\mu \mathrm{m}$ ) and were then concentrated under reduced pressure at a temperature of $40^{\circ} \mathrm{C}$ and stored at a temperature of $-20^{\circ} \mathrm{C}$ until it used for further analysis. For screening the extracts of the Gynura procumbens, $100 \mathrm{mg}$ of the sample dissolved in $1 \mathrm{~mL}$ of DMSO to obtain a 100 $\mathrm{mg} / \mathrm{mL}$ stock solution of extracts. All extracts kept at $4^{\circ} \mathrm{C}$ throughout the experiment. Stock solutions further diluted in a RPIM-1640 (Sigma, MO, USA) media to obtain a final concentration of $100 \mu \mathrm{g} / \mathrm{mL}$.

\section{Cell Culture and Harvesting of U-87 Cell Line}

The Human Glioblastoma multiforme cell line (U-87) were purchased and maintained at a temperature of $37^{\circ} \mathrm{C}$ in a humidified $\mathrm{CO}_{2}$ incubator with $5 \% \mathrm{CO}_{2}$ in RPMI-1640 media supplemented with $10 \%$ fetal bovine serum and $1 \%$ of antibiotic. Cell medium changed every 3 days and the cells reached confluence after a week of culture. Cells were maintained at $95 \%$ relative humidity while changing the media at least twice a week.

\section{MTT Assays and Determination of $I C_{50}$}

The anti-proliferative activity of extracts from the Gynura procumbens were obtained using the micro-titration colorimetric method of tetrazolium salt reduction, 3- [4, 5-dimethylthiazol-2-yl]-2-5-diphenyltetrazolium bromide (MTT) to determine cell viability. ${ }^{10}$ Exponentially growing cells were harvested, enumerated using the hemocytometer and diluted with a medium. A cell volume with a concentration of $1.0 \times 10^{4}$ cells $/ \mathrm{mL}$ was prepared and was plated $(100 \mu \mathrm{L} /$ well) into 96 -well plates (NUNCTM, Denmark). Before the addition of cells into the plates, the stock solution of Gynura procumbens was diluted with media, transferred into the wells and sequentially added to achieve the starting concentration of $100 \mu \mathrm{g} / \mathrm{mL}$ in DMSO and was serially diluted to achieve the concentration range of $100-0 \mu \mathrm{g} / \mathrm{mL}$.

After that, the Gynura procumbens extracts were plated out in triplicates. Each plate included untreated cells as control and a blank cell-free control. The anti-proliferative effect of each Gynura procumbens extract against untreated cells was measured in triplicate for a trial of $24 \mathrm{~h}, 48 \mathrm{~h}$ and $72 \mathrm{~h}$ respectively. After incubation, $20 \mu \mathrm{g} / \mathrm{mL}$ of MTT solution was added to each well to be re-incubated for another $4 \mathrm{~h}$ at the same conditions. Then, the media removed and $100 \mu \mathrm{L}$ of DMSO was pipetted into each well to solubilize the formazan crystals and incubated for another 15 min. Lastly, the absorbance measured at $570 \mathrm{~nm}$ by using ELISA micro-plate reader (TECAN, INFINITE M2000). The relative viability of the treated cells as compared to the control cells expressed as the percentage of cell viability count. The calculation of Cell Viability percentage: [570nm of treated cells] / [570nm of control cells] $\times 100 \%$.

\section{Morphology Studies of U-87 Cell Line}

The Human Glioblastoma multiforme cell line (U-87) was grown in 4 well plates and treated with extract residue from the leaves of Gynura procumbens obtained using ethanol, methanol, and ethyl acetate as a solvent. The morphology study run at a temperature of $37^{\circ} \mathrm{C}$ for duration of $0,24,48$, and $72 \mathrm{~h}$; morphological changes were occurring in the cells observed under a light microscope (Nikon, Japan).

\section{Data Analysis}

The SPSS 20.0 software employed for statistical analysis. Data expressed as mean $\pm \mathrm{SD}$ of three independent values.

\section{RESULT}

The methanol, ethanol and ethyl acetate extracts obtained from Gynura procumbens leaves tested for their ability to induce anti-proliferative activity on U-87 cell line (100 mg/mL,72 h) [Figure 1]. As shown in Table 1, all solvents revealed activity on U-87 cell line proliferation. However, the ethanol extract showed the highest inhibitory effects on the U-87 cell line proliferation with $1.5 \pm 0.04 \%$. This data followed by methanol and ethyl acetate extracts for anti-proliferative activity on U-87 cell line with $3.2 \pm 0.05 \%$ and $50.0 \pm 0.04 \%$. The potency of the effect evaluated by testing different concentrations $(100 \mathrm{mg} / \mathrm{mL}-0 \mathrm{mg} / \mathrm{mL})$ on U-87 cells proliferation with an incubation period of $0,24,48$ and $72 \mathrm{~h}$. In both extracts of methanol and ethanol, the anti-proliferative activity showed a time-dependent effect between 24 and 72 h. However, only the ethyl acetate extract of Gynura procumbens exhibited a time dependent inhibition of cell proliferation after $48 \mathrm{~h}$ of incubation.

Morphological changes of U-87 cell line assessed at 24, 48 and $72 \mathrm{~h}$ after treatment with Gynura procumbens extract for $72 \mathrm{~h}$ [Figure 2]. In the experiment, under treated control conditions $(0 \mathrm{~h})$, cells appeared healthy and grew up to $90 \%$ of confluences in methanol, ethanol and ethyl acetate extracts. For ethanol and methanol extracts, the U-87 cell line slowly exhibited the characteristic features of cell shrinkage, and partial detachment after $24 \mathrm{~h}$ as compared to control conditions $(0 \mathrm{~h})$. At $72 \mathrm{~h}$, cell lines incubated with ethanol extract continued to exhibit features of blebbing and demonstrated the lobulated appearance of loss normal shape. Meanwhile, cell lines incubated with ethyl acetate extract shows cells that looked smaller in size or shrunk stated as per N/C ratio (nuclear-cytoplasmic ratio) after $24 \mathrm{~h}$. Along with treatment until $72 \mathrm{~h}$, there is no major presence of cell shrinkage, rounding and partial detachment, floating of cell and lobulated appearance to be apoptotic cells.

\section{DISCUSSION}

Natural sources such as plants and fruits had been studied to be potential in curing cancer without giving excessive damage to normal body cells. The previous study also had supported that anticancer drug should have destroyed or inhibited cancer cells without causing excessive damage to normal cells. ${ }^{11}$ In this study, the anti-proliferative activity of methanol, ethanol and ethyl acetate extracts of Gynura procumbens in inhibiting the U-87 cell line determined by using MTT assay and determination of $\mathrm{IC}_{50}$ value. MTT assay is the basis for numerous in vitro assays that includes only the measurement of cell viability and proliferation. ${ }^{12}$ The $\mathrm{IC}_{50}$ value depended on relationship number of cells, amount of MTT formazan generated and duration of cell incubated. ${ }^{13}$

The present study had shown the anti-proliferative activity of Gynura procumbens extracts on U-87 cell line [Figure 1]. Crude extracts possessing an $\mathrm{IC}_{50}$ value less than $20 \mu \mathrm{g} / \mathrm{mL}$ are considered active against the tested cancer cells based on past studied. ${ }^{14}$ In the present study, ethanol and methanol extracts were found to show the highest inhibitory effects of U-87 cell line at $\mathrm{IC}_{50}$. This finding supported that ethanolic extract of Gynura procumbens shown to be effective against carcinogenic effect 


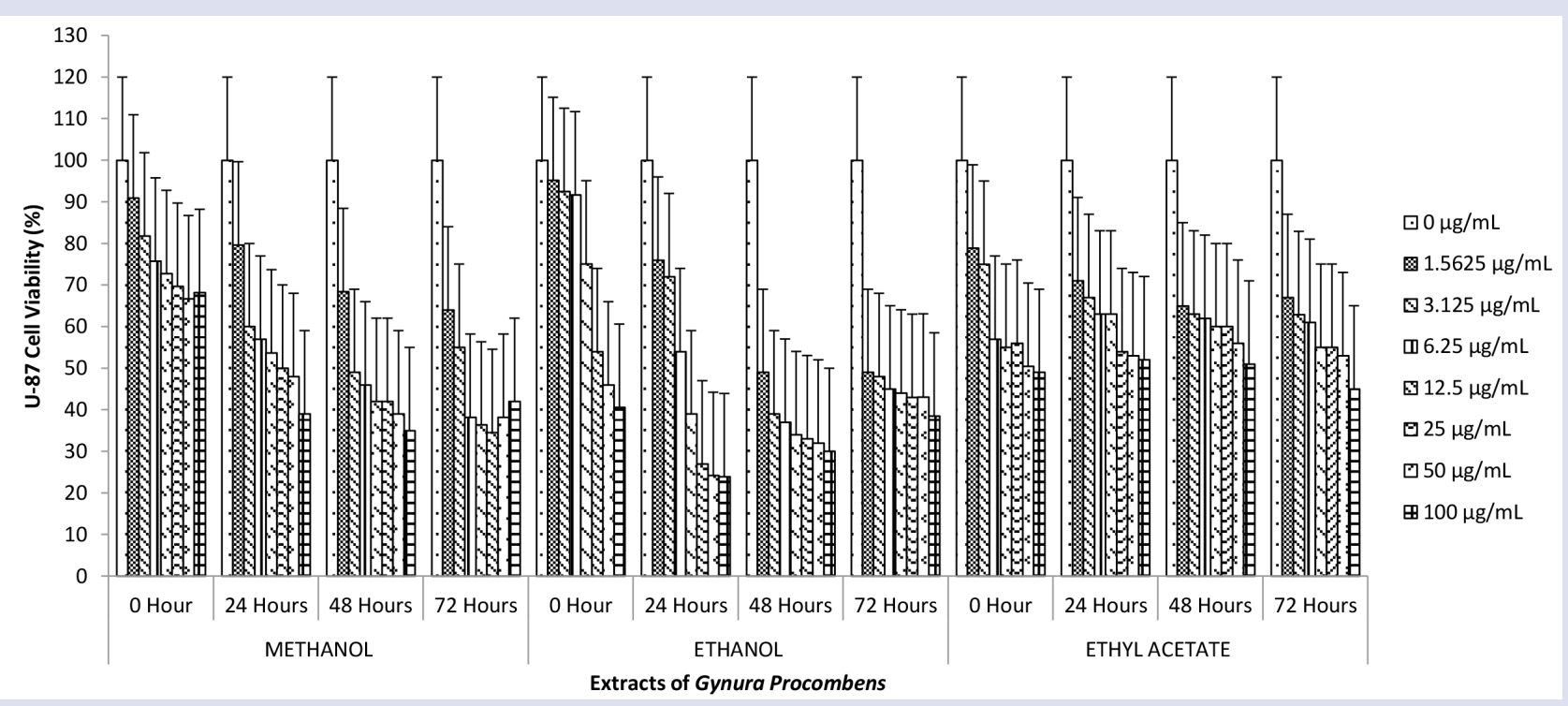

Figure 1: Inhibition of Human Glioblastoma Multiforme Cell Line (U-87) by Methanol, Ethanol and Ethyl Acetate extracts of Gynura procumbens leaves on time dependent at $0 \mathrm{~h}, 24 \mathrm{~h}, 48 \mathrm{~h}$ and $72 \mathrm{~h}$.

* Values shown are means of 3 independent experiments. The cell growth of treated groups was standardized with untreated control group as A/ $\mathrm{A} 0(\%)$, where A is the value of A570 generated at a given concentration of extracts by MTT assay, A0 is from untreated control group.

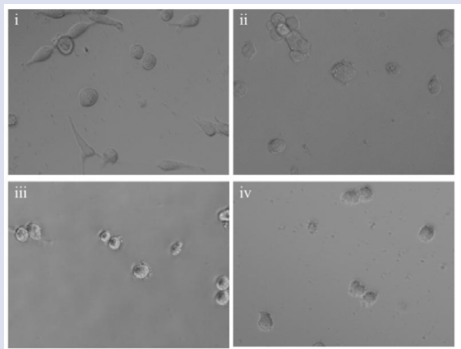

Inhibition of Human Glioblastoma Multiforme cell lines (U-87) by methanol extract of Gynura Procumben leaves for 3 days.
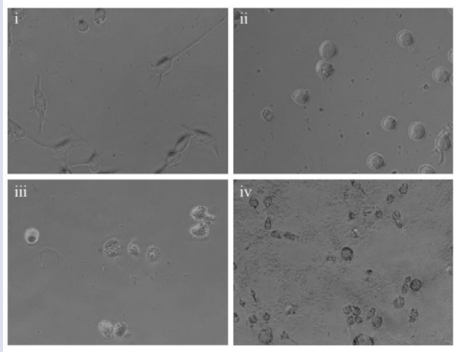

b. Inhibition of Human Glioblastoma Multiforme cell lines (U-87) by
ethanol extract of Gynura Procumben leaves for 3 days.
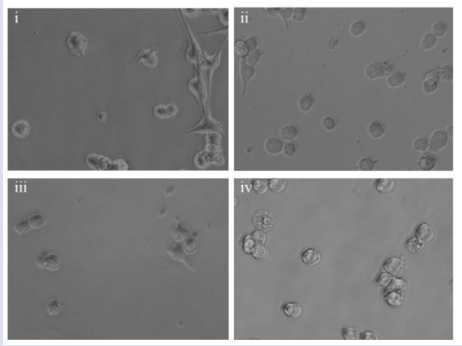

Inhibition of Human Glioblastoma Multiforme cell lines (U-87) by ethyl acetate extract of Gynura Procumben leaves for 3 days.

Figure 2: Cell morphological pattern of U-87 cell line after treated with Gynura procumbens extract at 0 (i), 24 (ii), 48 (iii) and 72 (iv) h. The photographs were taken at $\times 20$ magnification with inverted microscope (Nikon, Japan).
Table 1: Anti-proliferative effect of U-87 cell line by methanol, ethanol and ethyl acetate extracts of Gynura procumbens.

\begin{tabular}{ccc}
\hline \multicolumn{3}{c}{ IC $_{\mathbf{5 0}}$ Value $(\boldsymbol{\mu g} / \mathbf{m L})$} \\
\hline Gynura procumbens Extracts & U-87 Cell Line \\
\hline Methanol & 0 Hour & NA \\
& $24 \mathrm{H}$ & $23.6 \pm 0.01$ \\
& $48 \mathrm{H}$ & $3.2 \pm 0.05$ \\
Ethanol & $72 \mathrm{H}$ & $4.0 \pm 0.01$ \\
& $0 \mathrm{Hour}$ & $31.5 \pm 0.03$ \\
& $24 \mathrm{H}$ & $7.50 \pm 0.05$ \\
& $48 \mathrm{H}$ & $1.5 \pm 0.04$ \\
Ethyl Acetate & $72 \mathrm{H}$ & $1.5 \pm 0.08$ \\
& $0 \mathrm{Hour}$ & $50.0 \pm 0.04$ \\
& $24 \mathrm{H}$ & $\mathrm{NA}$ \\
& $48 \mathrm{H}$ & $\mathrm{NA}$ \\
& $72 \mathrm{H}$ & $72.0 \pm 0.07$ \\
\hline
\end{tabular}

DMBA on liver. ${ }^{15}$ The treatment had shown inhibition of cell proliferations; suppress the invasive and migratory abilities of cancer cells. ${ }^{16}$

Gynura procumbens extracts appear to be a potential source of natural antioxidants may due to its high phenolic content. ${ }^{17}$ In the other hand, the content of total phenolic in Gynura procumbens extracts can listed in the decreasing order of methanol, ethanol and aqueous. ${ }^{18}$ The result was contrasted with a present study, the inhibitory effects listed in the decreasing order of ethanol, methanol and ethyl acetate. There is past study that detailed that as an extract from the plant covers numerous different active biological compounds, it is possible that the irregularity of Gynura procumbens benefits is due to batch variation, in which certain batches may have high total phenolic than another batch. ${ }^{19}$ 
The statement also was supported by others, ${ }^{20}$ while there is various amount of phenolic and non-phenolic compound dependence on the extraction solvent used for extraction procedure. Despite the discrepancy between $\mathrm{IC}_{50}$ values, the morphological changes had yet exhibited the characteristic features of blebbing and lobulated appearance to be apoptotic cells of U-87 cell lines incubated with ethanol extract. Morphological changes in a cell committing apoptosis can initially visualized under a light microscope. ${ }^{21}$ However, specific mechanism of anti-proliferative activity of Gynura procumbens extracts needs to add in the future for more efficacy result.

\section{CONCLUSION}

Gynura procumbens extracts had tested for their potential anti-proliferative activity in U-87 cell line. The result showed that the ethanol extract explicated potential anti-proliferative effects compared to methanol and ethyl acetate extracts which reflecting the potential use in future as an alternative therapy. With present result and literature reviews, this plant could be an important source of safer cytotoxic compounds with further exploration. Therefore, there is a need to further explore potential and benefits of methanol and ethanol extracts of Gynura procumbens at molecular levels and revealed the important chemical constituents and bioactive molecules, responsible for anti-proliferative activity.

\section{ACKNOWLEDGEMENT}

The authors would like to thank the Ministry of Higher Education, Malaysia and Universiti Sultan Zainal Abidin (UniSZA) for the financial aid (UNISZA/2015/DKP/23) and the Faculty of Health Sciences for providing the facilities. The authors would also like to acknowledge all staffs from Teaching Laboratory 1, Faculty of Medicine and Faculty of Health Sciences, UniSZA.

\section{CONFLICT OF INTEREST}

The authors declare no conflict of interest.

\section{ABBREVIATIONS USED}

\%: percentages; $\mu \mathrm{g} / \mathrm{mL}$ : microgram per milliliter; $\mu \mathrm{L} /$ well: microlitre per well; $\mu \mathrm{m}$ : micrometer; cells $/ \mathbf{c m}_{2}$ : cells per centimetre square; $\mathbf{C O}_{2}$ : carbon dioxide; DMSO: dimethyl sulfoxide; IC $_{50}$ : half maximum inhibition concentration; $\mathbf{m g} / \mathbf{m L}$ : milligram per milliliter; MTT: tetrazolium salt 3- [4, 5-dimethylthiazol-2-yl]-2-5-diphenyltetrazolium bromide; N/C: nuclear-cytoplasmic; $\mathbf{n m}$ : nanometer; ${ }^{\circ} \mathrm{C}$ : degree Celcius; w/v: weight per volume; min: minutes; h: hours.

\section{REFERENCES}

1. Chong PKS, Loo AVP. Visual epilepsy in Glioblastoma Multiforme. Medicinal Journal of Malaya. 2008;63(5):406-7.

2. Wang-Gillam A, Siegel E, Debra AM, Hutchins LF, Zhou YH. Anti-Tumor effect of Doxycycline on Glioblastoma cells. Journal of Cancer Molecules. 2007;3(5):147-53.

3. Kaewseejan N, Siriamornpun S. Bioactive components and properties of etha- nolic extract and its fractions from Gynura Procumbens leave. Industrial Crops and Products. 2015;74:271-8.

4. Waris G, Ahsan $\mathrm{H}$. Reactive oxygen species: role in the development of cancer and various chronic conditions. Journal of Carcinogen. 2006;5:14.

5. Krishnan V, Ahmad S, Mahmood M. Antioxidant potential in different parts and callus of Gynura Procumbens and different parts of Gynura bicolor. Biomedical Research International. 2015;1-7.

6. Hew CS, Khoo BY, Gam LH. The anti-cancer property of protein extracted from Gynura procumbens (Lour.) Merr. Plus, One. 2013;8(7):1-10.

7. Rasidah, Yam MF, Sadikun A, Ahmad M, Akowuah GA, Amawi MZ. Toxicology evaluation of standardized methanol extract of Gynura Procumbens. Journal of Ethnopharmacology. 2009;123(2):244-9.

8. Tan LTH, Lee LH, Yin WF, Chan CK, Abdul Kadir H, Chan KG, et al. Traditional uses, phytochemistry, and bioactivities of Cananga odorata (Ylang-Ylang). Evidence Based Complementary and Alternative Medicine. 2015.

9. Khalili MAR, Norhayati AH, Rochman N, Atif AB, Khairil M. Study on Antioxidant Capacity and Anticancer Activity of Bismillah Leaf (Vernonia Amygdalina). World Journal of Pharmaceutical Research. 2014;3(6):14-29.

10. Khalili MAR, Mimie NJ, Norhaslinda R, Norhayati AH, Salwani I, Ariff TMRH, et al. Anti-proliferative effect of Duku (Lansium Domesticum Corr) extracts on Human Coloractal Adenocarcinoma Cell lines. Research Journal of Pharmaceutical, Biological and Chemical Sciences. 2016;7(2):1078-84.

11. David H. Vegetables, Fruits and phytostrogens in the prevention of diseases. Journal of Postgraduate Medicine. 2004;50:145-9.

12. Rohin MAK, Ridzwan N, Jumli MN, Hadi NA, Johari SATT, Latif AZA. Cytotoxicity study and morphological changes of different extraction for Bismillah leaves (Vernonia amygdalina) in human Glioblastoma multiforme cell lines (U-87). 2017;28 (2):1-7.

13. Mosmann T. Rapid colorimetric assay for cellular growth and survival: application to proliferation and cytotoxicity assays. Journal of Immunology Methods. 1983;65:55-63.

14. Chen WX, Yan GH, Li JL. Numerical Taxonomic Study of Fast-Growing Soybean Rhizobia and a Proposal that Rhizobium fredii be assigned to sinorhizobium gen. International Journal of Systematic Bacteriology. 2008;38(4):392-7.

15. Nisa F, Hermawan A, Murwanti R, Meiyanto E. Antiproliferative effect of Gynura Procumbens (Lour.) Merr. leaves ethanolic extract on 7, 12- dimethylbenz(a)antracene induced male rat liver. Advance Pharmaceutical Bulletin. 2012;2:99-106.

16. Wang H, Zhou JW, Fu DH, Zhou Y, Cheng WZ, Liu ZL. Gynura procumbens ethanolic extract suppresses osteosarcoma cell proliferation and metastasis in vitro. Oncology Letters. 2013:6:113-7.

17. Rosidah, Yam M, Sadikun A, Asmawi M. Antioxidant potential of Gynura procumbens. Pharmaceutical Biology. 2008;46:616-25.

18. Afandi A, Zulkiffli HM, Sadikun A. Ismail S. Antioxidant properties of Gynura procumbens extract and their inhibitory effects on two major human recombinant sytochrome P450S using a high throughput luminescence assay. Asian Journal of Pharmaceutical Clinical Research. 2014;7(5):36-41.

19. Wong FC, Woo CC, Hsu A, Tan BKH. The Anti-cancer activities of Vernonia amygdalina extract in human breast cancer cell lines are mediated through Caspase dependent and p53-independent pathways. PLoS ONE. 2013;8:e78021.

20. Sun T, Ho CT. Antioxidant activities of buckwheat extracts. Food Chemistry. 2005:90(4):945-8.

21. Latifah, SY. Cytotoxic Properties of Anthraquinones (Nordamnacanthal and Damnacanthal) From Roots of Morinda Elliptica. Phd Thesis. University Putra Malaysia. 2003. 
GRAPHICAL ABSTRACT

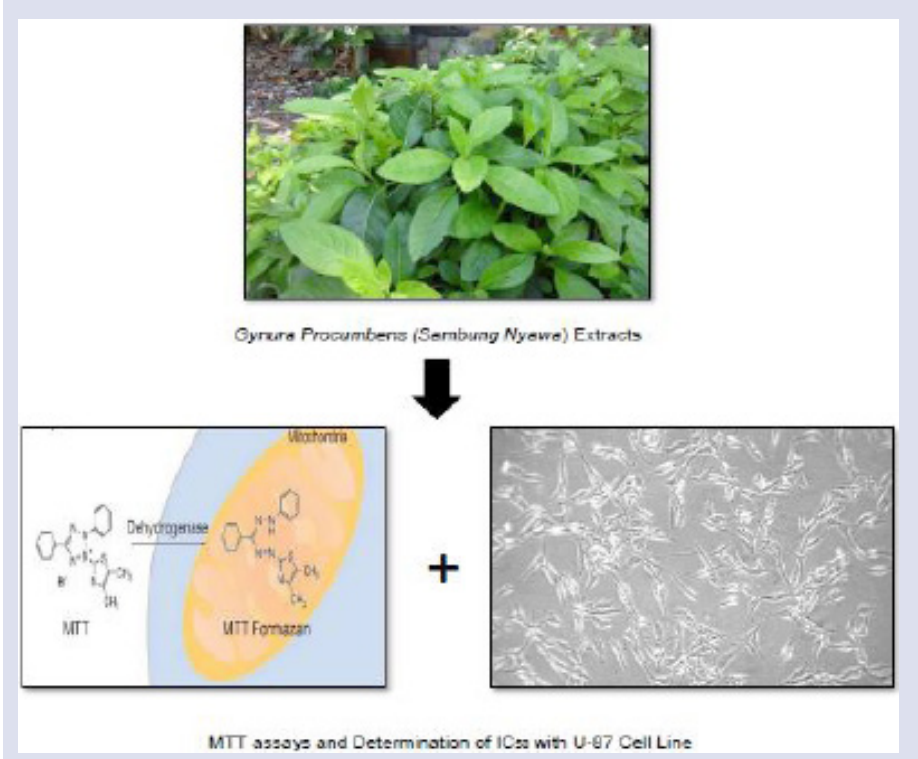

\section{SUMMARY}

- This paper is the first report about anti-proliferative effects of Gynura procumbens extracts on U-87, glioma cells.

- Three different polarity solvents were used to extract Gynura procumbens leaves which is methanol, ethanol and ethyl acetate.

- Ethanol and methanol extracts of Gynura procumbens were found to have high anti-proliferative effect on U-87 cell line with $\mathrm{IC}_{50}$ less than $20 \mathrm{\mu g} / \mathrm{mL}$.

- U-87 cell line exhibited the characteristic features of cell shrinkage, and partial detachment after $24 \mathrm{~h}$ as compared to control conditions $(0 \mathrm{~h})$.

\section{ABOUT AUTHORS}

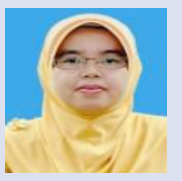

Mrs. Norhayati Abd Hadi: Obtained a Bachelor's Degree from Universiti Malaysia Terengganu (UMT) in Food Service and Nutrition (2000 - 2003) and Master's degree from Universiti Putra Malaysia (UPM) in Clinical Nutrition (2003 - 2006). Work as Senior Lecturer at Universiti Sultan Zainal Abidin (UniSZA) and specializes in the Nutrition and Psychology Promotion, Nutrition and Food and Hospitality Services fields. Currently, she is pursuing a PhD in Universiti Malaysia Terengganu (UMT) for a study on the effects of honeybee and stingless bee honey supplementation on subjects with cardiovascular risk factors.

Cite this article: Rohin MAK, Jumli MN, Ridzwan N, Baig AA, Latif AZA, Hadi NA. Effects of Gynura procumbens Extracts on AntiProliferative Activity and its Associated Morphological Changes of Human Glioblastoma Multiforme Cell Line (U-87). Pharmacog J. 2018;10(3):492-6. 